ISSN : 2746-7155 (Online), ISSN : 1978-4996 (Print)

MAKILA:Jurnal Penelitian Kehutanan Volume 13, Nomor 2 (130-138)

DOI : http://doi.org/10.30598/makila.v13i2.2439

®2019 Jurusan Kehutanan UNPATTI

\title{
Analisis Rantai Pemasaran Produk Industri Meubel PD. Tabulik
}

\author{
(Analysis of the Marketing Chain of Furniture PD. Tabulik Industry Products)
}

Imlabla Wilma N.1* Samuel Limba1, Mersiana Sahureka1 ${ }^{1}$ \& Makbul A. Keliwouw²,

1Jurusan Kehutanan, Fakultas Pertanian, Universitas Pattimura, Ambon, 97233

2Mahasiswa Jurusan Kehutanan, Fakultas Pertanian, Universitas Pattimura, Ambon, 97233

*Email : wilma.imlabla@faperta.unpatti.ac.id

\begin{abstract}
The PD. Tabulik furniture industry is one of the furniture industries that is believed to be superior in global competition. Therefore, strategic policies related to the optimal marketing chain are needed in maintaining business sustainability amid market competition. Consequently, the research aims to analyze the marketing chain of furniture industry products. The research method uses survey methods and in-depth interviews with all marketing channel components and the marketing chain analysis of the research object's outcome. The results show that the marketing chain is used by PD. Tabulik is a short marketing channel model that is direct producers to end consumers and is still limited in the Maluku region. The products' marketing chain gets shorter and shorter, so the final consumer is not charged with the purchase cost. But PD.Tabulik needs to fix the marketing chain management and marketing mix efficiently and optimally.
\end{abstract}

KEYWORDS: marketing chain, furniture industry, business sustainability, marketing mix

\section{INTISARI}

Industri meubel PD. Tabulik merupakan salah satu industri meubel yang diyakini dapat menjadi unggulan dalam menghadapi persaingan global. Oleh kerena itu dibutuhkan kebijakan strategis terkait rantai pemasaran yang optimal dalam mempertahankan kelestarian usaha di tengah persaingan pasar. Penelitian bertujuan untuk menganalisis rantai pemasaran produk industri meubel. Penelitian menggunakan metode survey dan wawancara mendalam dengan semua komponen saluran pemasaran dan analisis rantai pemasaran produk dari obyek penelitian. Hasil penelitian menunjukkan bahwa rantai pemasaran yang digunakan PD.Tabulik adalah model saluran pemasaran pendek yakni produsen langsung kepada konsumen akhir, dan masih terbatas di wilayah Maluku. Rantai pemasaran produk semakin pendek rantai pemasaran, maka konsumen akhir tidak dibebankan atas biaya pembelian. Namun PD.Tabulik perlu membenahi manajemen rantai pemasaran dan marketing mix secara efisien dan optimal.

KATA KUNCI : rantai pemasaran, industri mebel, marketing mix

\section{PENDAHULUAN}

Sektor kehutanan memegang peranan strategis bagi pembangunan ekonomi nasional salah satunya adalah industri pengolahan kayu yang mengalami perkembangan yang cukup pesat. Sampai saat ini industri perkayuan berskala kecil sudah berkembang mencapai dimensi sangat vital, baik sebagai sumber pasokan devisa maupun dalam 
memperluas lapangan kerja dan kesempatan berusaha yang mendorong berkembangnya pembangunan di daerah-daerah terpencil.

Sektor swasta sebagai mitra turut memberikan kontribusi yang cukup besar bagi pendapatan negara.Saat ini semua industri pengolahan kayu di Maluku berperan aktif dalam mengelola hasil hutan berupa kayu menjadi berbagai macam produk hasil hutan yang salah satu di antaranya kayu gergajian, dimana keberadaan industri-industri ini dirasakan sangat memberikan kontribusi yang sangat besar terhadap pendapatan negara maupun daerah Maluku sendiri.

Industri meubel PD. Tabulik adalah salah satu industri lokal kehutanan di kabupaten Seram Bagian Timur yang dalam pengelolaanya menjadi skala prioritas pemerintah SBT.Upaya membangun jejaring dan promosi produk dari industri meubel ini sangat gencar dilakukan. Selain memperkuat promosi di daerah Maluku secara keseluruhan, juga dipamerkan pada arena pekan raya Jakarta (PRJ), selain itu juga perna show room di singapura dan telah mengirim contoh ke italia dan kanada untuk di promosikan. Salah satu bentuk perhatian nyata dari pemerintah Seram Bagian Timur (SBT) terkait dengan pengembangan industri meubel ini adalah dengan membangun jaringan dagang dengan pihak-pihak yang bergerak di bidang meubeler dan juga pangsa pasar di Asia, Eropa, dan Amerika (Rahyantel, 2015). Industri meubel PD. Tabulik menjadi salah satu industri meubel yang diyakini bisa menjadi unggulan Kabupaten SBT dalam menghadapi persaingan global. Oleh kerena itu dibutuhkan kebijakan strategis yang mendukung bagi industri meubel. Terkait dengan rantai pemasaran yang merupakan proses aliran komoditi yang disertai perpindahan hak milik barang atau jasa yang dilakukan oleh lembagalembaga pemasaran yang baik bisa menjadi unggulan serta dapat mempertahankan kelestarian usahanya dalam menghadapi persaingan dengan melaksanakan satu atau lebih fungsi-fungsi pemasaran (Makkarennu et al. 2017). Bantuan dari sisi pemesinan juga bisa dilakukan agar dapat meningkatkan kualitas produk yang dihasilkan sehingga nantinya bisa berpengaruh pada peningkatan ekspor bagi industri meubel nasional.

Industri meubel PD. Tabulik untuk dapat lebih siap dalam menghadapi persaingan selain mendapat ancaman seperti banyak pesaing, dalam pengembangan juga tak terlepas dari pengaruh ketersediaan bahan baku, permasalahan ketenagakerjaan, daya saing, iklim investasi, serta teknologi dll. Olehnya itu dituntut untuk lebih bekerja keras dalam mencermati dan mengantisipasi reaksi lingkungan eksternal dan internal perusahaan yang mendukung, kekuatan dan kelemahan industri meubel PD. Tabulik serta peluang dan ancamannya. Sehingga dapat dirumuskan rantai pemasaran yang tepat bagi industi meubel PD. Tabulik dalam pengembangannya untuk lebih survive dan competitive. Peningkatan produksi baik dari segi kualitas maupun kuantitas tidaklah berguna apabila tidak 
diimbangi dengan sistem pemasaran yang baik atau tata niaga yang mendukung. Pemilihan saluran pemasaran merupakan faktor penting bagi suatu industri meubel, seperti PD. Tabulik, karena dapat mempengaruhi keputusan industri meubel di bidang pemasaran. Sehingga di upayakan industri meubel seperti PD. Tabulik lebih memperhatikan saluran pemasarannya agar setiap produk yang di produksi tetap tersalur dengan baik, sehingga dapat meningkatkan animo pembeli (konsumen) dalam memperoleh setiap produk sesuai kebutuhannya yang dihasilkan, sehingga diharapkan ini sebagai bentuk upaya sekaligus solusi untuk mempertahankan kelestarian usahanya dalam pengembangan industri meubel PD. Tabulik selanjutnya, karena seperti yang kita ketahui bahwa kualitas sebesar apapun produk yang dihasilkan namun tidak diimbangi dengan sistem pemasaran yang baik atau efisien maka produk-produk yang diproduksi tersebut akan tidak tersalur dengan baik, dan jika sampai hal itu terjadi maka yang pastinya akan mengurangi animo pembeli (konsumen), maka PD. Tabulik mengharapkan supaya produk serta sistem pemasaran yang dihasilkan dapat memuaskan atau memenuhi kebutuhan pembeli (konsumen).

Pemasaran dikatakan efektif apabila konsumen atau pemakai industri dapat terpenuhi kebutuhannya dengan produk yang dihasilkan secara kontinyu. Namun keuntungan yang dihasilkan pedagang perantara relatif kecil apabila hanya sebagai penghubung dari produsen ke konsumen akhir Wulandari et al. (2018). Jika produk yang dihasilkan oleh produsen sifatnya tahan lama maka produsen tidak perlu menggunakan fasilitas khusus untuk menyampaikan produknya, tetapai apabila produk yang dihasilkan itu sifatnya lekas rusak atau bentuknya dapat cepat berubah maka produsen memerlukan fasilitas khusus dan jasa-jasa lembaga pemasaran agar produknya dapat dipasarkan dan disampaikan dengan cepat kepada konsumen, oleh karena itu diharapkan supaya industri meubel seperti PD. Tabulik untuk juga lebih memperhatikan jenis produk yang diproduksi agar tidak membutuhkan rantai pemasaran yang rumit serta bersifat ekonomis. Untuk menentukan jumlah produk yang dipasarkan produsen harus menentukan skala produksinya dan meninjau potensi dari lembaga-lembaga pemasaran untuk memasarkan sejumlah besar produknya hingga sampai ditangan konsumen/pembeli. Hal ini berkaitan dengan kuatnya keuangan dan luasnya daerah pemasaran. Berdasarkan uraian di atas maka penelitian ini bertujuan untuk menganalisis rantai pemasaran produk industri meubel dalam mempertahankan kelestarian usaha.

\section{METODE PENELITIAN}

\section{Lokasi dan Waktu Penelitian}

Penelitian ini dilakukan pada industri meubel PD Tabulik di kampong Gorom, Kecamatan Bula, Kabupaten Seram Bagian Timur, berlangsung selama Januari -Februari 2018. 
Analisis Rantai Pemasaran Produk Industri Meubel PD. Tabulik

(Imlabla Wilma N. Samuel Limba, Mersiana Sahureka, \& Makbul A. Keliwouw)

\section{Metode Penelitian}

Metode yang digunakan dalam penelitian ini adalah metode survey, dimana pengambilan data dilakukan dengan pengamatan langsung di lapangan dan pengisian kuesioner (daftar pertanyaan). Pengumpulan data dilakukan dengan cara:

a. Observasi yaitu pengumpulan atau pengambilan data dengan melakukan pencatatan secara cermat dan sistematik melalui hasil pengamatan. Pengamatan dilakukan secara langsung di lokasi PD Tabulik, Desa Kampung Gorom, Kecamatan Bula, Kabupaten Seram Bagian Timur.

b. Melakukan wawancara yaitu dengam melakukan komunikasi langsung antara peneliti dan pengelola industri meubel serta para karyawan dengan menggunakan kuesioner.

\section{Analisa Rantai Pemasaran}

Analisa Rantai pemasaran menggunakan analisis deskriptif kualitatif. Analisis ini dilakukan untuk menjelaskan rantai pemasaran jenis produk dan marketing mix yang ada pada PD Tabulik maupun konsumen untuk memperoleh informasi.

\section{HASIL DAN PEMBAHASAN}

\section{Produksi}

Produksi meubel yang dilakukan PD.Tabulik dalam satu bulan sebesar $10-20 \mathrm{~m}^{3}$ bahan baku. Ketersediaan bahan baku di Seram Bagian Timur yang cukup tentu saja akan memberikan dampak positif pada industri meubel PD.Tabulik dalam kelancaran melakukan produksi., sementara produk yang dihasilkan dalam satu bulan sebanyak 11 produk dengan kapasitas yang didukung dengan mesin yang memadai dan lengkap serta dengan teknologi yang maju. Mengingat desain produk merupakan kunci dalam proses produksi, maka bagian produksi terus berusaha untuk mempersiapkan karyawannya dengan memberikan pelatihan desain dan juga meningkatkan inovasi dari karyawan dalam memproduksi produk.

\section{Marketing Mix}

Marketing Mix adalah kombinasi dari kegiatan-kegiatan pemasaran yang dilakukan untuk memasarkan barang dan jasa tertentu selama periode waktu tertentu kepada pasar tertentu. Kegiatan-kegiatan yang dimaksud meliputi keputasan-keputusan tentang 4 variabel yaitu Produk, Harga, Distribusi dan Promosi. (Hise, 1997). Marketing mix yang ada pada PD.Tabulik hanya terdapat 3 variabel yaitu produk, harga dan promosi.

\section{Produk}

Konsep produk mengatakan bahwa konsumen akan menyukai produk yang menawarkan mutu, performansi dan ciri-ciri yang terbaik. Tugas managemen disini adalah 
membuat produk berkualitas, karena konsumen dianggap menyukai produk berkualitas tinggi dalam penampilan dengan ciri-ciri terbaik.

Industri meubel PD. Tabulik untuk jenis produknya aneka meubeler (tergantung pemesanan, dan ada pembuatan rumah kayu juga). Semua produk yang diproduksi oleh industri meubel PD.Tabulik terjamin kualitasnya karena semua bahan baku utama yang digunakan adalah berasal dari jenis-jenis kayu yang berkualitas seperti kayu Lenggua, Kayu Besi, Makila, Jati dan lain-lain. Selain itu, untuk menjamin kualitas bahan baku, setelah bahan baku diperoleh perusahaan dari pemasok, proses pengeringan dan pengawetan kayu dilakukan dengan teratur sehingga bahan baku terhindar dari rayap perusak kayu serta pengaruh lain yang membuat kualitas kayu menurun. Adapun bahan mentah yang diperoleh yaitu dari dalam kota Bula sendiri.

\section{Harga}

Harga suatu barang dan jumlah barang yang diperjualbelikan ditentukan oleh permintaan dan penawaran dari barang tersebut. Oleh karena itu, untuk menganalisis mekanisme penentuan harga dan jumlah barang yang diperjualbelikan maka perlu dilakukan analisis permintaan dan penawaran atas suatu barang tertentu yang terdapat dipasar. Keadaan suatu pasar dikatakan seimbang apabila jumlah yang ditawarkan penjual pada suatu harga tertentu adalah sama dengan jumlah yang diminta para pembeli pada harga tersebut. Harga suatu barang dan jumlah barang yang diperjualbelikan ditentukan dengan melihat keadaan ekuilibrium dalam suatu pasar. Keadaan ekuilibrium tersebut dapat ditunjukan sebagai berikut : (Sukirno, 2005). Harga produk yang ditetapkan oleh industri meubel PD.Tabulik masih berdasarkan standarisasi yang ditetapkan oleh industri meubel PD.Tabulik itu sendiri. Harga produk diantaranya dapat dilihat pada Tabel 1.

Tabel 1. Harga Produk Industri Meubel PD.Tabulik

\begin{tabular}{clcccc}
\hline No & Jenis Barang & Harga & Satuan & $\begin{array}{c}\text { Jumlah } \\
\text { Produksi }\end{array}$ & Nilai \\
\hline 1 & Kursi tamu & 7.000 .000 & SET & 1 (SATU) & 7.000 .000 \\
2 & Kursi makan & 5.000 .000 & SET & 5 (LIMA) & 25.000 .000 \\
3 & Lemari pakaian & 3.000 .000 & PISIS & 3 (TIGA) & 9.000 .000 \\
4 & Tempat tidur & 2.500 .000 & PISIS & 2 (DUA) & 5.000 .000 \\
5 & Gazebo & 10.000 .000 & UNIT & 2 (DUA) & 20.000 .000 \\
6 & Rumah kayu & 100.000 .000 & UNIT & 1 (SATU) & 100.000 .000 \\
7 & Kursi kuliah & 400.000 & BUAH & 100 (SERATUS) & 40.000 .000 \\
8 & Meja kantor & $2,500.000$ & BUAH & 2 (DUA) & 5.000 .000 \\
9 & Meja tivi & 3.000 .000 & SET & 2 (DUA) & 6.000 .000 \\
10 & Partisi & 4.000 .000 & SET & 2 (DUA) & 8.000 .000 \\
11 & Kosen pintu & 400.000 & SET & 2 (DUA) & 8.00 .000 \\
\hline \multicolumn{7}{c}{ Total Nilai Dari Jumlah Produk } & & $\mathbf{2 2 5 . 8 0 0 . 0 0 0}$ \\
\hline
\end{tabular}

Sumber : Data Primer (2019) 
Analisis Rantai Pemasaran Produk Industri Meubel PD. Tabulik

(Imlabla Wilma N. Samuel Limba, Mersiana Sahureka, \& Makbul A. Keliwouw)

\section{Promosi}

Promosi adalah kegiatan memberitahukan kepada konsumen tentang adanya barang/jasa dengan harga tertentu. Sebagaimana yang telah dikemukakan sebelumnya bahwa pemasaran merupakan titik temu/saluran antara pasar dengan perusahaan. Dengan demikian pemasaran memainkan peran rangkap yaitu sebagai penganjur perusahaan, perusahaan mempromosikan produk melalui periklanan, promosi penjualan dan kunjungan penjualan untuk mendapatkan pesanan. Pemasaran juga memainkan peran utama dalam dukungan pasca jual kepada pelanggan dan produk untuk menjamin kepuasan pelanggan yang membantu proses menagih piutang, memperoleh pesanan lanjutan dan yang sangat penting memberikan referensi positif kepada calon pelanggan (Saimima, 2010; Sopi'ah, 2016).

Kegiatan promosi industri meubel PD. Tabulik belum dilakukan secara optimal. Pemasaran industri meubel PD.Tabulik meluas melalui promosi dari satu pelanggan ke pelanggan lainnya. Selama ini promosi masih terbatas dilakukan dengan menyesuaikan event-event nasional di Maluku berupa pameran seperti pada hari Keluarga Nasional, MTQ Nasional, dan sebagainya. PD.Tabulik sampai saat ini belum melakukan promosi secara online seperti lewat website dan lain-lain.

\section{Rantai Pemasaran}

Serangkaian organisasi yang saling bergantung yang terlibat dalam proses menjadikan produk atau jasa siap untuk digunakan atau siap di konsumen merupakan pengertian saluran pemasaran (Kotler, 2002). Baik tidaknya saluran distribusi yang digunakan oleh sebuah perusahaan itu dipengaruhi oleh kondisi perusahaan itu sendiri maupun pasarnya. Menurut Swastha (1999). Penetapan mata rantai dapat dibedakan atas saluran distribusi langsung kepada konsumen. Saluran distribusi pendek dimana produsen menggunakan satu jalur untuk memasarkan produksinya yaitu melalui pengecer, kemudian saluran pemasaran panjang yaitu produsen mengadakan penjualan dalam jumlah yang besar kepada pedagang besar atau eksportir. Saluran pemasaran yang sangat panjang dimana produsen menggunakan beberapa penyalur sehingga proses pemasarannya panjang untuk sampai ke konsumen. Ada 4 (empat) model saluran pemasaran/distribusi menurut swastha (1987), yaitu:

a. Produsen --- Pemakai Industri

Saluran distribusi secara langsung ini menyangkut volume penjualan dalam rupiah yang relatif cukup besar dari barang industri dibandingkan dengan saluran yang lain. Produsen barang industri seperti lokomotif, mesin pembangkit tenaga listrik, dan barang industri meubel. 
b. Produsen --- Distribusi Industri --- Konsumen Akhir

Produsen barang-barang jenis operating dan accessory dan accessory equipment kecil dapat menggunakan distributor industri untuk mencapai pasarnya, antara lain produsen bagian bangunan, alat-alat untuk konstruksi bangunan, alat pendingin udara (AC) dan sebagainya.

c. Produsen --- Agen --- Konsumen Akhir

Biasanya saluran distribusi semacam ini dipakai oleh produsen yang tidak memeliki departemen pemasaran.Apabila suatu perusahaan yang ingin memperkenalkan produk baru atau ingin memasuki daerah pemasaran baru atau lebih suka menggunakan agen.

d. Produsen --- Agen --- Distributor Industri --- Konsumen Akhir

Saluran distribusi semacam ini dapat dipakai oleh perusahaan dengan pertimbangan antara lain bahwa unit penjualannya terlalu kecil untuk dijual secara langsung, atau mungkin memerlukan penyimpanan pada penyalur. Berdasarkan hasil wawancara dengan kepala bagian produksi selaku koordinator, pada penilitian yang penulis lakukan menunjukan bahwa saluran pemasaran yang digunakan PD.Tabulik yaitu menggunakan model saluran pemasaran yang pertama yakni dari Produsen langsung kepada Pemakai Industri/Konsumen Akhir, untuk saat ini rantai pemasaran yang ada pada PD.Tabulik masih terbatas di seputar wilayah Maluku. Ada yang di luar Maluku, tetapi pemesanannya hanya lewat Whatsapp seperti (Manado, Sorong, Makasar, dan Jakarta). PD.Tabulik juga melakukan pemasaran melalui katalog-katalog produk yang disebarluaskan, melalui pameran produk pada kegiatan-kegiatan nasional di Maluku seperti pada Hari Keluarga Nasional, MTQ Nasional dan lain sebagainya.

Secara skematis model saluran pemasaran dapat dilihat pada Gambar 1. Rantai Pemasaran.

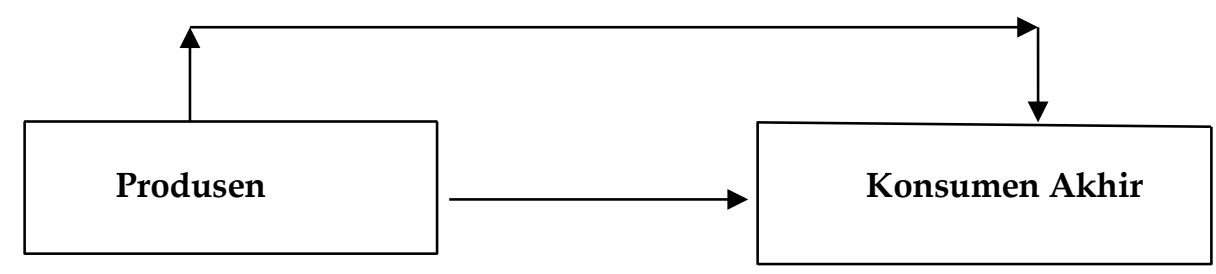

Gambar 2. Model Rantai Pemasaran PD.Tabulik

Gambar saluran pemasaran menunjukan bahwa harga hanya melibatkan produsen dan konsumen akhir. Saluran pemasaran PD.Tabulik dimaksudkan untuk lebih mudah dan jalur memperoleh keuntungan lebih cepat dan langsung karena tidak ada harga yang 
dikeluarkan untuk kegiatan pemasaran atau distribusi produk ke pedagang akhir. Dengan demikian, rantai distribusi langsung dari produsen ke konsumen yang dilakukan oleh PD Tabulik saluran distribusi langsung (direct chanenel of distribution) yaitu penyaluran barangbarang atau jasa-jasa dari produsen ke konsumen dengan tidak melalui perantara, dengan melakukan penjualan di tempat produksi, penjualan di showroom atau melalui pameran.

Beberapa faktor yang mempengaruhi pemasaran suatu produk antara lain :

1. Harga menjadi penentu pertama dalam menentukan minat para konsumen dan juga menjadi penentu keberlangsungan barang yang diproduksi. Apabila harga yang ditentukan relatif rendah tentunya minat konsumen juga akan semakin meningkat. Pada intinya harga penjualan barang produksi harus lebih tinggi dari harga pembelian bahan baku dan biaya produksi.

2. Daya saing produk-produk yang ditawarkan memiliki kualitas yang baik karena berasal dari bahan baku kayu Besi, kayu Lenggua, Jati dan Makila. Dengan demikian bisa bersaing dengan baik mulai dari pesaing produk barang yang sejenis, dan juga dari pesaing barang yang memiliki nilai kegunaan yang sama.

3. Pemanfaatan teknologi merupakan faktor pengaruh yang sangat besar dalam memperlihatkan dan memasarkan suatu produk kepada konsumen sehingga lebih cepat dan efisien. Pemanfaatan teknologi dengan adanya peralatan produksi yang lengkap dan dikendalikan oleh mesin. Sedangkan untuk pemasaran produk dan promosi dilakukan dengan memanfaatkan teknologi informasi melalui media sosial.

4. Pembeli atau peminat merupakan faktor yang berpengaruh dalam proses pemasaran, yang nantinya akan berpengaruh dalam proses penjualan produk,

PD. Tabulik merupakan satu-satunya meubel milik daerah dengan demikian pemerintah daerah turut berperan dalam peningkatan produksi dan pengembangan usaha meubel. Disisi lain PD Tabulik dapat dikatakan menguasai pangsa pasar daerah karena meubel-meubel/atau usaha lainya merupakan milik swasta dan masih dalam skala kecil. Hal ini dapat dilihat dari kualitas produk serta jenis produk PD.Tabulik yang begitu variatif dan berdasarkan pesanan yang diinginkan pembeli/konsumen.

\section{KESIMPULAN}

Marketing Mix Industri Meubel PD.Tabulik menggunakan 3 variabel utama yaitu : Produk, Harga dan Promosi. Industri Meubel PD.Tabulik tidak melakukan kegiatan distribusi produk secara langsung.

Rantai pemasaran yang digunakan PD.Tabulik yaitu model rantai pemasaran pendek yakni dari produsen langsung kepada konsumen akhir. Rantai pemasaran yang ada pada PD.Tabulik saat ini masih terbatas di seputar wilayah Maluku. 


\section{DAFTAR PUSTAKA}

Kartasapoetra, G. 1992. Marketing Produk Pertanian dan Industri. Jakarta: Rineka Cipta.

Kotler.P, 2001. Manajemen Pemasaran, Analisis Perencanaan, Implementasi dan Kontrol. PT. Prehallindo, Jakarta.

Makkarennu, M., Nakayasu, A., Osozawa, K., and Ichikawa, M. 2017. An Analysis of the Demand Market of Indonesia Plywood in Japan. International Journal of Sustainable Future for Human Security 2(2): 2-7. DOI: 10.24910/jsustain/2.2/27

Murad.Y, 2001. Analisis Saluran Pemasaran Sortimen Kayu Gergajian Pada UD. Murlia di Desa Kawa Kecamatan Seram Barat, Kabupaten Seram Bagian Barat.

Rahyantel.Z, 2015. Strategi Pengembangan Industri Meubel Dalam Menghadapi Masyarakat Ekonomi ASEAN (Studi Kasus Pada Industri Meubel PD.Mitra Karya Kabupaten Seram Bagian Timur).

Saimima S. 2010. Analisis Perkembangan Produksi dan Pemasaran Kayu Gergajian Jenis Kayu Besi (Studi Kasus Pada Industri Penggergajian UD.Amin) di Kebun Cengkeh, Desa Batu Merah, Kecematan Sirimau, Kota Ambon. Universitas Pattimura, Ambon.

Sopi'ah. 2016. Studi Perkembangan Produksi dan Pemasaran Kayu Gergajian Jenis Kayu Meranti Merah (Shorea selanica), Pada Industri Pengolahan Kayu PT. Katingan Timber Celebes di Desa Wamlana Kecamatan Fena Leisela Kabupaten Buru. [Skripsi]. Universitas Pattimura, Ambon

Stanton, Wiliam J. 2001. Prinsip Pemasaran Jilid ketuju. Penerbit Erlangga, Jakarta

Swastha B. 1987. Manajemen Barang Dalam Pemasaran, BPFE, Yogyakarta.

Swastha, B. 1999. Azas-Azas Marketing. Liberty. Yogyakarta.

Winardi. 1991. Marketing dan Perilaku Konsumen. Bandung : Mandar Maju

Wulandari, D., Qurniati, R., \& Herwanti, S. 2018. Efisiensi Pemasaran Durian (Durio Zibethinus) di Desa Wisata Durian Kelurahan Sumber Agung. Jurnal Sylva Lestari 6(2): 68-76. DOI: $10.23960 /$ js12668-76 